\title{
THE VOICE FROM THE PERIPHERY: TOWARDS AN AFRICAN BUSINESS ETHICS BEYOND THE WESTERN HERITAGE
}

\author{
M F Murove
}

University of KwaZulu-Natal, Unilever Ethics Centre

This article argues that African business ethics should go beyond the western heritage by taking into account African indigenous values and knowledge systems. While western business practices are part and parcel of Africa's heritage, African post-colonial scholarly efforts have worked at enriching this heritage by arguing for the incorporation of African indigenous knowledge systems and values in our way of thinking and doing business. There is a realisation that the western homo economicus who is solely self-interested is irreconcilable with the African understanding of a person. The success of any business venture in Africa depends on incorporating African values in the way it operates.

JEL B00, M00

1

\section{Introduction}

I will start the argument of this paper by submitting that a distinction must be made between business ethics in Africa and African business ethics. My main motive for making such a distinction arises from the fact that authentic scholarly reflection on the way Africans conduct their businesses has always been overshadowed by the influence of western business practices. Contemporary scholarly works on African indigenous values and business ethics seem to presume that African indigenous values can be made commensurate with business as it has been inherited from the west during the colonial interlude.

The African western heritage of business practices finds its articulation in what I see as the two dominant theses. The first thesis is based on the argument that the idea of business ethics in post-colonial Africa is implausible because Africa's colonial heritage has made it impossible to reflect on ethical practices in business activities. Closely related to this argument is the presumption that the post-colonial state did not make things easy for the emergence of business ethics in Africa. Values such as accountability, fairness and transparency have never been practised in colonial and postcolonial political practices.

The second thesis says that business activities in Africa that were based on the values of western capitalism could not succeed in Africa because western capitalism was basically and originally incompatible with African cultural, economic and religious values. Values that have enabled glorious economic success in the western world were simply unintelligible to the African mind. Still within this thesis, there are some western as well as African scholars who argue that for Africa to reverse its sorry economic situation, it has to make some pragmatic move from a communally orientated moral outlook to an individualistic outlook. This thesis is a reiteration of the Weberian thesis that said that the Protestant ethics of individualism facilitated the evolution of modern capitalism in the western world.

In the light of these theses, African business ethics constitutes a voice from the periphery in the sense that mainstream voices in business ethics seem to ignore the would-be contributions of African values to the emergence of African business ethics. While 
Africa might have inherited business practices from western capitalism, the argument that is also advanced in this paper is that through the inclusion of African values and indigenous knowledge systems, a paradigm shift must occur in African business practices if ever African businesses are to secure a competitive advantage in the global business community. While the western economic tradition is part and parcel of Africa's business heritage, this heritage might have contributed to Africa's economic problems, especially that heritage of a businessperson as being solely self-interested.

\section{2 \\ Business ethics and the Western heritage}

Scholars from various cultural and religious backgrounds are generally in consensus that business ethics are primarily concerned with behaviour that is deemed conducive for the operation of business. Among western classical liberal economists and political philosophers, human economic and political behaviour was mainly understood as being motivated by selfinterest. Western classical economic theorists such as Bernard de Mandeville, Adam Smith, Philip Wicksteed, to mention just a few, understood human economic behaviour as being solely self-interested. In the eighteenth century, a Dutch physician, Bernard de Mandeville, wrote a little parody called Fable of the Bees in which he argued that all those vices that were condemned by moralists were the cause of the flourishing of wealth. As he puts it:

Vast numbers thronged the fruitful Hive;

Yet those vast Numbers made 'em thrive;

Millions endeavouring to supply

Each others' Lust and Vanity

Thus every part was full of Vice

Yet the whole Mass a paradise

To enjoy the world's conveniences,

Be famed in war, yet live in ease

Without great vices, is vain

Utopia seated in the brain (Mandeville, 1994: 1: 18, 9).
According to Mandeville, things that were beneficial to society came from private vices. All those deplorable human qualities such as avarice, vanity, luxuriousness and ambition actually caused wealth to flourish. Moralists might condemn them, but those vicious causes led to public benefits. Adam Smith, the father of laissez faire capitalism, wove his Wealth of Nations partly on Mandeville's claim that selfishness was the main reason for wealth to flourish. Smith is popularly known for having taught that in business relations people should not rely on the benevolence of a businessperson for their needs, but rather on appeasing his or her self-interest. Thus he stated "We address ourselves not to their humanity but to their selflove, and never talk to them of our necessities, but of their advantages" (Smith, 1976: 27). The implication here was that there is no altruism in business relations. Rather, it is all about appealing to each other's self-interest. Being self-interested was not something bad because "By pursuing his own self-interest [a business person] frequently promotes that of the society more effectually than when he intends to promote it" (Smith, 1976: 413). While businesspeople were solely self-interested, the results of their actions ended up benefiting everybody in society with whom they have no concern at all (Poole, 1991: 8).

Such presumptions about business relations resulted in a divorce between business practices and ethics. Philip Wicksteed emphasised this divorce when he advanced the argument that business relations have nothing to do with our sentiments and evaluations. The pursuit of selfinterest in business relations was supposed to be understood as morally neutral. The idea of analysing business relations on the basis of egoism versus altruism was not relevant because "The economic relation, then, or business nexus, is necessary alike for carrying on the life of the peasant and the prince, of the saint and the sinner, of the apostle and the shepherd, of the most altruistic and the most egotistic of men [sic]" (Wicksteed, 1946: 171).

In other words, business relations are supposedly value neutral. This value neutrality of business relations can further be discerned from the fact that sometimes " $[\mathrm{t}]$ he group of 
men who unite to propagate a set of religious doctrines or to call attention to a social or national wrong, or to secure a sanitary dietary reform, or to preach any gospel...will want the means of procuring specified services from persons outside their ranks" (Wicksteed, 1946: 171). When doing business, the other person's moral standing on the issue in question is irrelevant. Wicksteed maintained that ethical evaluations in business relations do not come into play because a businessperson "is exactly in the position of a man who is playing a game of chess or cricket. He is considering nothing except the game. It would be absurd to call a man selfish for protecting his king in a game of chess, or to say that he was actuated by purely egoistic motives in so doing"(Wicksteed, 1946: 173). Here it can be deduced that Wicksteeed's argument was that we need to refrain from making moral judgements about business relations because a business relation "has no inherently moralising power" (Wicksteed, 1946: 180-183). The implication of Wicksteed's argument of value neutrality is that business relations have nothing to do with our moral predispositions.

However, the severing of morality from business relations has been the subject of criticism of classical liberal economy. John Ruskin, one of the ardent critics of classical economic liberalism, argued that business relations that were solely motivated by selfinterest would be dehumanising. Thus he avers "Men of business do indeed know how they themselves made their money, or how, on occasion, they lost it. Playing a long-practised game, they are familiar with the chances of its cards, and can rightly explain their losses and gain" (Ruskin, 1898: 39). Here Ruskin equated business relations with a game in which one has to know the rules that should determine the outcomes of one's desired goals. In playing this game, as Ruskin put it, "What is really desired, under the name of riches, is, essentially, power over men; in its simplest sense, the power of obtaining for our own advantage the labour of servant...the authority of directing large masses of the nation to various ends (good, trivial, or hurtful, according to the mind of the rich person)" (Ruskin, 1898: 44-45). Ruskin stated pragmatically that "the art of becoming 'rich', in a common sense, is not absolutely or finally the art of accumulating much money for ourselves, but also of contriving that our neighbours shall have less. In accurate terms, it is "the art of establishing maximum inequality in our favour" (Ruskin, 1898: 45). In a nutshell, Ruskin's argument was that business activities that were done purely in the mundane pursuit of self-interest were dehumanising. The dehumanising aspect of business relations under liberal capitalism lay in the fact that such relations shunned moral values such as generosity, compassion and sympathy towards fellow human beings.

The legacy of classical economic liberalism on business relations is that it reduced all human motivations to greed and selfishness. One of the neo-liberal economists, Paul Heyne, advanced the argument that whatever one might see as being for the public, is actually a product of self-interest. He writes, "We should be well advised to discount all the rhetoric about public versus private interests, and to look for the incentives that actually shape the decisions that people take" (Heyne, 1983: 273). The incentives that Heyne saw as the cause of human decisions in business, are those that promote one's self-interest. His advice in this regard is that "The way to advance one's self-interest is to expand each activity whose marginal cost is greater than its marginal revenue" (Heyne, 1983: 273). The logic of the above principle is that for one to advance one's self-interest, one has to always act only in those circumstances or situations where the outcome of one's business activities will lead to the promotion of one's self-interest.

However, Deon Rossouw criticised this neoliberal economic theory of self-interest on the grounds that "business is social in nature". Therefore, "concern for others' interests as well as your own is essential if you want to run a sustainable business" (Rossouw, 2002: 13). Rossouw argued further that ethics are indispensable from business relations. Thus he writes:

Business environments where unethical conduct is rampant scare off investors who 
fear for their property, investment, or even their lives. Further, the wider community generally shows intolerance towards unethical business practices that undermine justice and safety. Business that threatens social stability normally results in calls for stronger government intervention in economic affairs. ...So unethical behaviour can result in penalties or the exclusion of certain businesses, and can even endanger the future of the business enterprise itself. (Rossouw, 2002: 15)

The implication of Rossouw's argument as stated above is that ethics are indispensable to business relations in the sense that it is to the advantage of business to enter into ethical business relations. We can deduce in the light of Rossouw's argument that the idea of business relations as being solely dominated by selfinterest, is implausible. In the same vein, George Chryssides and John Kaler expressed their reservations towards self-interest on the grounds that the pursuit of self-interest in business relations should be done concurrently with "the collective self-interest of society". According to Chryssides and Kaler, "Without that organising principle, not just business activity, but social life in general, would be impossible. There would just be competing selfinterest without reconciliation" (Chryssides \& Kaler, 1999: 34). The implication here is that the understanding of business as being solely dominated by self-interest equally implies an anarchic conceptualisation of society.

While there has been a paradigm shift from a conceptualisation of business relations as being solely dominated by self-interest to the idea of the indispensability of business relations to ethics, other African scholars are arguing that the success of capitalist development in Africa is only possible if there is an ethical move from communally orientated social ethics to ethics of individualism. The argument is that the economic system that was inherited by postcolonial Africa originated from western individualistic values; therefore Africa should embrace individualistic values if it is to succeed in economic development. In other words, the problem for business relations in Africa must be traced to Africa's colonial economic history that has been predominantly a litany of a clash of values. This clash of values can be discerned from the fact that the profit motive that has dominated western business practices since the inception of capitalism does not find the same driving force in business relations in Africa.

3

\section{Colonial Africa and the advent of capitalism}

Western economic liberalism arrived in Africa through colonialism, Islam and Christianity. The Christian belief in an individual soul that was solely accountable to God contributed to the implantation of the ethics of individualism in Africa. The Christian doctrine of individual salvation instead of community salvation provided the genesis for individualism. The Christian evangelisation mission was based on teaching converts that they were accountable before God rather than the community. The African communal spirit was to be exorcised on the belief that it was contrary to the idea of individual accountability.

The African historian John Iliffe adopted Marx Weber's theory that says there is a symbiosis between Protestant ethics and the spirit of capitalism. Iliffe argued that there was an early connection between the Christian ethics of individualism and the emergence of capitalism in Africa. According to Iliffe, Jehova's Witnesses provided some values in Africa that were conducive to the success of capitalistic business practices in Africa. He writes, "First, certain of the Witnesses' specific teachings aided a businessman: the importance of literacy (in order to read the scriptures), the careful use of time, the notion that to acquire skills was to have them ready for the New Kingdom. Second, to be a Witness was to belong to solidary community whose mutual trust gave its members an entrepreneurial advantage" (Iliffe, 1983: 45-46). Iliffe's argument is that the spirit of capitalism or individual entre-preneurship was introduced to Africa by western Christianity. This type of argument presupposes that the spirit of 
capitalism was non-existent in pre-colonial African societies.

It is also Iliffe's argument that Christianity facilitated the African economic evolution from traditional communalism to capitalism. Iliffe observed that during the times of colonialism, Albert Atcho of the Ivory Coast, a founder of an African Christian sect, preached a peculiar type of Christianity that among other things, emphasised the importance of entrepreneurship. Iliffe said that while Atcho was a healer, his healing activities were aimed at individuals rather than communities. As he put it, "Atcho healed individuals; he did not stress the restoration of harmony to groups...And it was entirely in keeping with the association of spiritual force with material prosperity that he should have been not an ascetic but a wealthy entrepreneur" (Iliffe, 1983: 48). It is clear that Iliffe connected the emergence of African entrepreneurship with the ethic of individualism. Thus he avers, "There is very little indication that indigenous institutions aided the emerging capitalist" because in traditional African communities capitalist entrepreneurship is associated with witchcraft (Iliffe, 1983: 52). This observation can be authenticated by the fact that in many African societies successful entrepreneurs are mostly suspected of using human body parts as a way of attracting customers to their businesses.

In the same vein, Paul Kennedy attributed the lack of entrepreneurial spirit in Africa to the fact that African tradition is inhibitive to the spirit of free enterprise. He observes, "Thus, entrepreneurs who wish to operate within a kinship or community situation, where the social pressures against individual acquisitiveness and mobility remain and 'big men' are expected to redistribute wealth, must find some way to resolve a central contradiction" (Kennedy, 1988: 140). Kennedy's presumption is that African communities are closed systems that do not welcome economically innovative ideas. It is for this reason that he saw the Christian factor in Africa as actually promoting the evolution of the spirit of entrepreneurship. According to Kennedy, those who were converted to Christianity were able to put their innovative business ideas into practice under the pretext of religion. As he put it, "Church membership provided religious justification, spiritual protection and practical assistance for the converts in their struggle to disentangle themselves from the demands of their matrikin and concentrate instead on building up their business and nuclear family interests" (Kennedy, 1988: 142). Kennedy's argument is that the spirit of entrepreneurship among Africans originated with the ethics of individualism which was disseminated by Christianity, as it disentangled individuals from communal relationship and put emphasis on teaching that individuals were accountable for their own actions instead of communities.

Apart from the influence of the Christian religion, Kennedy also argued that Islam played a vital role in the emergence of capitalism in Africa. According to Kennedy, Islamic conversion provided "the same 'release' both from the demands of kin and community in time and capital and from the fear of group hostility towards those who are perceived as to be selfseeking" (Kennedy, 1988: 48). Once released from these traditional social and religious relations, Kennedy stated that individuals were able to enter into business relations without fear of traditional sanctions. Thus he writes,

...the Islamic ban on the consumption of alcohol and certain foods, as well as the need to follow a partly separate ritual and social life, all provided the opportunity for entrepreneurs to reduce their level of involvement in traditional society. Yet this behaviour no longer incurred community displeasure since it was now judged to be religiously determined rather than the result of selfish individualism (Kennedy, 1988: 142).

Kennedy's argument is that religious conversion, either to Christianity or Islam, contributed to the emergence of African entrepreneurship. Christianity and Islam became a way of escaping traditional African communalism. Within this type of reasoning, the traditional African community is presumed to be a stumbling block to entrepreneurship and capitalistic development. Thus one finds 
Stephen Theron rebuking Augustine Shutte for advocating the ethics of Ubuntu as follows:

As for the ethical implications, the proverb simply side-steps the slow Western development of the idea of personal responsibility, charted in the Bible and elsewhere, and now known to Africans. Without this consciousness the fruit of technology cannot be enjoyed. The proverb teaches Africans to evade responsibility, rather, to hide behind the collective decision of the tribe (Theron, 1995: 35).

The implication of Theron's argument is that Africa's lack of economic development should be traced to the fact that Africans understand themselves in terms of communal belonging, with the emphasis on collective responsibility. The success of capitalistic development depends on Africa's readiness to embrace the ethics of individualism instead of the traditional ethics of collectivism. However, there are scholars who trace the failure of business in postcolonial Africa to the problem of juxtaposing western business values on African ones.

Thus, Ali Mazrui traced the litany of Africa's poor economic performance to the fact that "Africa as a whole borrowed the wrong things from the West - even the wrong components of capitalism. We borrowed the acquisitive appetites of capitalism but not the creative risk taking" (Mazrui, 1990: 5). In other words, capitalistic values that became integral to African business enterprises were incompatible with business values in western capitalism. Mazrui made the same argument in his article "Towards Year 2000" when he said "Capitalism has come to Africa with an imperative of acquisition without the discipline of work and frugality". But not only that, "The white man himself in Africa set a dangerous example. He never washed his own clothes, or cooked his own food, or polished his own shoes, or made his own bed, or cleaned his own room, or even poured his own gin and tonic". It is because of this type of behaviour that was displayed to the Africans as characteristic of capitalism that made western capitalism implausible to comprehend. Hence, "The luxurious aristocratic life of white settlers as they played masters to African servants was detrimental to the spirit of capitalism the white man himself had arrived with" (Mazrui, 1999: 492-493; cf. Iliffe, 1983: 54-55).

Mazrui went on to argue that this twisting of values resulted in post-colonial business practices that encouraged "ostentatious consumption" without production. This twisting of values could be observed from the fact that "[w]hile the profit motive in classical economic theory was supposed to lean toward greater production, the prestige motive in contemporary African economic behaviour leans towards greater consumption" (Mazrui, 1999: 492-493). In this type of economic behaviour, Mazrui argued that the capitalistic Protestant ethics of thrift, hard work and frugality have been severed from business relations in the post-colonial African scene.

While colonialism might have played a crucial role in the shaping of business practices in Africa, it is imperative that African business relations should go beyond this colonial and western heritage. Post-colonial African scholarly efforts to go beyond the western heritage in African business ethics can be seen in efforts made to include African indigenous knowledge systems and values. In these scholarly efforts, the main emphasis is put on the need to indigenise business so that it truly reflects the realities of the African context. Here it is argued that instead of applying western values in African business relations in order to incarnate the spirit of western capitalism, we should create the spirit of capitalism in our postcolonial African context by applying African indigenous knowledge systems and values.

\section{4}

\section{African business ethics beyond the western heritage through indigenous knowledge systems}

There are African scholars who argue that business practices that originated in the west are incompatible with the African world-view. This incompatibility is well pronounced when one considers the fact that the African world- 
view is basically relational. This relationality can be discerned from the fact that the African world-view was premised on the notion of internal relatedness with all that exists to the extent that there was no divide between the self and the phenomenal world. In African traditional society people experienced their existence as intrinsically tied to that of nature. Mazrui characterised this world-view as based on ecological concern rather than curiosity. As he puts it "Ecological concern goes beyond mere fascination. It implies a commitment to converse and enrich...It requires a readiness on the part of man [sic] to see a little less of himself, and a little more of his God, in his surroundings. Ecological concern is an aspect of morality in its quest for sympathy" (Mazrui, 1977: 262).

In a world that has become so sensitised to issues of environmental well-being in relationship to business activities, the African world-view provides fertile ground for business practices that take the environmental well-being into account. But this can only be possible if business practices can help the process of reconstructing African traditional ecological knowledge systems. Matsvai and Nussbaum realised the importance of such a task when they pointed out that in Africa "there is undoubtedly a vast knowledge based on the ecological endowment of the region and how people used to live with and sustain their lives through nature, and how they managed the natural resource base..." (Matsvai \& Nussbaum, 1996: 200). The main problem, as Matsvai and Nussbaum saw it, is that "since local businesses are largely owned and run by managers who value hard, rational, scientific research rather than the more spiritual, interpersonal wisdom of a traditional ecologist", it is difficult for these western-trained managers to appreciate African indigenous knowledge systems (ibid.).

In the same vein, Mike Boon observed that African traditional people "have shared what is now considered as an extremely advanced First World way of thinking. They saw themselves as custodians, realising that if they destroyed the environment they could not survive. ...This wisdom still lives in tribal societies" (Boon, 1996: 49). Here we have an explicit appreciation of African indigenous knowledge systems, especially that of environmental conservation. However, western companies have sometimes been able to utilise African indigenous knowledge systems in their efforts to produce new products. The tendency of shying away from utilising African indigenous knowledge systems is aggravated by the fact that most of the companies in Africa prefer exotic knowledge systems to the African ones. It is also common knowledge that foreign or exotic plants have sometimes caused ecological disasters in the indigenous environment and its ecological systems in many parts of Africa. The ideal is that business must subsist in its contextually given social and natural environment (cf. Ake, 1996: 21). Sensitivity to one's context requires that African businesses should be cautious about what they import and whether import-substitution can be effected by investigating what the African environment can provide. However, another aspect of indigenisation that will help African business ethics to go beyond the western heritage is to indigenise business practices through the incorporation of African indigenous values in business practices.

\section{5}

\section{Beyond the western heritage through values of indigenisation in African business ethics}

Proponents of indigenisation through African indigenous values argue that the inclusion of African indigenous values in business would give business a new image in communities. Mvume Dandala argued that the African ethics of Ubuntu should be made integral to business management and production processes. He writes, "[U]buntu cannot be a concept that is easily distilled into some methodological procedure. ...It is the key factor that lies at the core of human relationships, innovation and ultimately productivity". Dandala went on to observe that " $[\mathrm{t}]$ he lifestyle in the mould of Ubuntu will embrace both the concepts of belonging for its members and people-friendly for its other stakeholders" (Dandala, 1996: 80). 
The implication of Dandala's argument is that in the African ethics of Ubuntu, emphasis is placed on our relationality with each other. Within these ethics, human judgements and actions should always express a sense of concern and care for the well-being of the community (Ramose, 1991: 53; Kasenene, 1994: 141-142; Prozesky, 2003: 5-8).

A sense of care for the well-being of others arises from the African understanding of a human being as a being by virtue of belonging to others. Within this presumption of human beings, it also follows that human beings have a causal influence on each other ontologically (Ramose, 1999: 62-64; Mazrui, 1986: 295). The implication of this understanding of human beings for African business ethics is that business relations are ethically plausible when they enhance the flourishing or ultimate well-being of communities. Human beings are not solely self-interested; rather they are endowed with a propensity to belong in a way that is all embracive. Thus, Ubuntu implies a humane treatment of people where they are not seen as part and parcel of production costs like the machines that are used in production processes. Ubuntu also implies that one cannot hire and retrench people primarily on the grounds of profitability calculus. Those who are committed to the ethics of Ubuntu are challenged to take into account the sufferings of people caused through decisions that are deliberately taken to effect retrenchments. While it can be acknowledged that business relations have an inescapable element of dehumanisation, the ethics of Ubuntu require that the focus of our business relations should lead to the promotion of the ultimate well-being of everybody through the humane treatment of people.

Within an African traditional context, parents teach their children Ubuntu as a way of perpetuating humanness into the future. Wealth accumulated in the present is also intended for future generations. The notion of accumulating wealth for the sheer thrill of it is at odds with the African attitude towards wealth as enshrined in Ubuntu. Julius Nyerere rebuked the idea of endless accumulation when he said " $[\mathrm{t}]$ he creation of wealth is a good thing and something

we shall have to increase. But it will cease to be good the moment wealth ceases to serve human beings and begins to be served by human beings" (Nyerere, 1968: 319). Nyerere's contention was that the means and ends of acquiring wealth should lead to human flourishing instead of dehumanising. The converse of the ethics of Ubuntu would be a philosophy of functionalism, whereby people are evaluated and treated according to their functions in the production process. When people are valued primarily according to the functions, they lose a sense of belonging in relationship to their workplaces.

The primacy of belonging in the ethics of Ubuntu originates from the fact that African rationality is primarily a relational rationality. Leopold Senghor cannot be bettered when he said that "African reasoning is intuitive by participation" according to which the subject and object of observation, the natural and supernatural, the mundane and the divine, the material and the spiritual are united in an inseparable oneness (Senghor, 1964: 72-74). It is partly for this reason that Africans internalise their business relations, especially those companies and institutions they work for. Boon made a very crucial observation when he said that among Africans "there's a moral and emotional response to doing business" (Boon, 1996: 60). The implication of this observation is that Africans are more ready to identify themselves with their working environments as well as with those with whom they enter into business relations. It follows that humane treatment of people is indispensable to ethical business relations within the African context.

6

\section{Conclusion}

In this study I started by showing that the western presumption of business relations as being solely dominated by self-interest will be at odds with African business ethics. I have argued that African business ethics should go beyond the western heritage by focusing on what the African context offers to business.

There are those African scholars who argued that Christianity and Islam introduced the spirit 
of capitalism and entrepreneurship to Africa. The gist of this argument is that these two religions separate individuals from their communities. By implication, this way of reasoning assumes that African traditional society is hostile to the spirit of entrepreneurship. It is argued that the failure of capitalistic development in Africa can equally be traced to the problem of juxtaposing western business practices on African realities. To overcome this problem, I suggested that African business practices can only bring about effective economic change by going beyond the western heritage. I have also shown that attempts to go beyond the western heritage are through the inclusion of African indigenous knowledge systems and values.

\section{References}

1 AKE, C. (1996) Democracy and Development in Africa, Brookings Institution: Washington.

2 BOON, M. (1996) The African Way: The Power of Interactive Leadership, Zebra Press: Sandton.

3 BUJO, B. (1998) The Ethical Dimension of Community: The African Model and the Dialogue Between North and South, Kolbe Press: Limuru.

4 CHRYSSIDES, G.D. \& KALER, J.H. (1999) An Introduction to Business Ethics, International Thomson Business Press: London.

5 DANDALA, H.M. (1996) "Cows never die: Embracing African Cosmology in the process of economic growth", in Lessem, R. \& Nussbaum, B., Sawubona Africa: Embracing Four Worlds in South African Management, Zebra Press: Johannesburg: 69-85.

6 HANDY, C. (1995) The Hungry Spirit: Making Sense of the Future, Arrows Books Limited: London.

7 HEYNE, P. (1983) The Economic Way of Thinking, Science and Research Associates: Washington.

8 KASENENE, P. (1994) "Ethics in African Theology" in Villa-Vicencio, C. \& De Gruchy, J., Doing Ethics in Context: South African Perspectives, David Philip Publishers: Cape Town: 138-147.

9 ILIFFE, J. (1983) The Emergence of African Capitalism, Macmillan: London.

10 KENNEDY, P. (1988) African Capitalism: The Struggle for Ascendancy, Cambridge University Press: Cambridge.
11 MANDEVILLE, B. (1924) The Fable of the Bees, 2, KAYE, F. B. (ed.), Oxford University Press: Oxford.

12 MATSVAI, S. \& NUSSBAUM, B. (1996) "Traditional ecology and modern business", in LESSEM, R. \& NUSSBAUM, B. (eds.) Sawubona Africa: Embracing four Worlds in South African Management: 192-214.

13 MAZRUI, A.A. (1976) On Heroes and Uhuru Worship: Essays on Independent Africa, Green \& Co Ltd: London.

14 MAZRUI, A.A. (1977) Africa's International Relations: The Diplomacy of Dependence, Heinemann: London.

15 MAZRUI, A.A. (1986) The Africans: A Triple Heritage, BBC Publications: London.

16 MAZRUI, A.A. (1999) "Towards Year 2000", in MAZRUI, A.A. and WONDJI, C. (eds.), General History of Africa VIII: Africa Since 1935, James Currey: London: 905-934.

17 NYERERE, J. (1968) Freedom and Socialism: Uhuru na Ujamaa, Oxford University Press: Oxford.

18 POOLE, R. (1991) Morality and Modernity, Routledge: London.

19 PROZESKY, M. (2003) Frontiers of Conscience: Exploring Ethics in a New Millennium, Equinym Publishing: Cascades.

20 RAMOSE, M.B. (1999) African Philosophy Through Ubuntu, Mond Books: Harare

21 ROSSOUW, D. (2002) Business Ethics in Africa, University Press: Oxford.

22 RUSKIN, J. (1898) Unto this Last, Penguin: Harmondsworth.

23 SAMKANGE, S. \& SAMKANGE, T.M. (1980) Hunhuism or Ubuntuism: A Zimbabwean Indigenous Political Philosophy, The Graham Publishing Company: Harare.

24 SENGHOR, L. (1964) On African Socialism, Macmillan: London.

25 SMITH, A. (1976) An Inquiry into the Nature and Causes of the Wealth of Nations, CAMPBELL, R. \& SKINNER, S. (eds.), Clarendon Press: Oxford.

26 THERON, S. (1995) Africa, Philosophy and the Western Tradition: An Essay in SelfUnderstanding, Peter and Lang $\mathrm{GmbH}$ : Frankfurt.

27 WEBER, M. (1930) The Protestant Ethic and the Spirit of Capitalism, Unwin Hyman: London.

28 WICKSTEED, P.H. (1946) The Common Sense of Political Economy and Selected Papers and Reviews on Economic Theory, Routledge: London. 